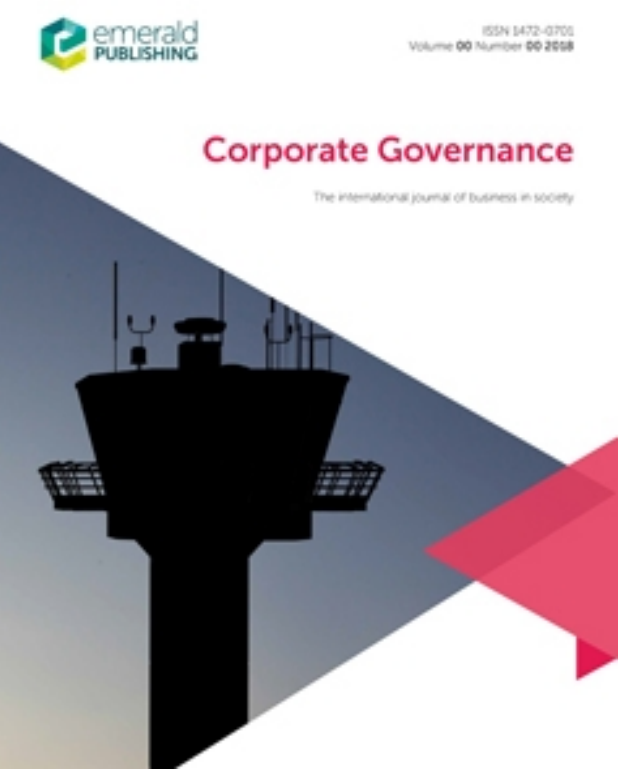

\title{
Evaluating the effectiveness of corporate boards
}

\begin{tabular}{|r|l|}
\hline Journal: & Corporate Governance \\
\hline Manuscript ID & CG-08-2018-0275.R2 \\
\hline Manuscript Type: & Original Article \\
\hline Keywords: & $\begin{array}{l}\text { Board of directors, Boardroom effectiveness, Boardroom performance, } \\
\text { Corporate Governance, Codes }\end{array}$ \\
\hline
\end{tabular}




\title{
Evaluating the effectiveness of corporate boards
}

\begin{abstract}
Purpose - This paper examines how board evaluations have emerged as an important tool in public policy and corporate practice for enhancing board effectiveness.

Design/methodology/approach - We review the extensive literature on effectiveness and the emerging literature on board evaluation to identify ways to assess the current policy direction for external evaluation of corporate boards.

Findings - The paper develops an integrated framework of effectiveness that can be used as a tool for board evaluation, in particular for externally facilitated exercises.

Research limitations/implications - Through its integration of prior conceptual work this paper advances our theoretical understanding of this emerging part of policy and practice, with to-date lack much empirical basis.

Practical implications - The framework we develop shows ways to focus how the practice is conducted by boards and external evaluators alike.

Social implications - It can also help policy formation by pointing out the limitations as well as benefits of various policy options.

Originality/value - In pointing to ways to develop study of the field through empirical research it provides direction for future academic research. It also identifies a need for and direction toward the professionalization of practice.
\end{abstract}

Keywords: Board evaluation, board effectiveness, corporate governance, directors 


\section{1. 'Where was the board?'}

After each of the many corporate collapses over the past quarter of a century, policymakers, practitioners and scholars alike have asked the question: Where was the board? That question begs others: What does it take to make a board effective? Indeed, what does it mean to say a board is effective? And how could we - policymakers, practitioners, scholars, or even directors themselves - evaluate whether it was effective?

The question of effectiveness has been the subject of much theorizing and empirical investigation. Studies using various measures of firm performance as a proxy for board effectiveness abound, though often with less than clear results. Can a board may be deemed effective when a firm outperforms its sector, if we cannot tell what in anything the board contributed? It makes sense to consider a board effective if it staves off disaster, say, by organizing an orderly retreat from a failing industry, or by preventing a faulty decision by a hubristic CEO. Such good results can go undetected by outsiders. Assessing performance on tasks closer to the board's direct span of action is difficult to do from afar. Board effectiveness, therefore, seems to be a local phenomenon, contingent on circumstances, involving relationships between directors in the execution of their roles.

While scholars may therefore have difficulty in identifying the conditions that constitute effectiveness, the practical and policy imperatives remain. Beginning in North America in the 1990s (Cadbury, 1999, describes the Toronto Stock Exchange move; see also NACD, 2001) and with increasing force over time, policy initiatives around the world have pressed the boards of companies to undertake regular, usually annual evaluations of their performance. Since the financial crisis of 2007-09, in the growing number of places that followed the lead of the UK Corporate Governance Code (FRC, 2010, 2018), policy has demanded that boards use external 
facilitators, in expectation of achieving greater objectivity. ${ }^{1}$ It quickly became a model for new codes for listed companies in other countries in many different settings (OECD, 2015).

The impetus for board evaluation has generated much advice from professional bodies (Jones, 2011), consultancies (McKinsey \& Co., 2011), and well-intentioned directors and other practitioners (Archer \& Cameron, 2017; Pitcher, 2014), practitioner articles in academic journals (Garratt, 1999; McIntyre \& Murphy, 2008), and practice-oriented writing by academics (Kakabadse, Kakabadse, Moore, Morais, \& Goyal, 2017; Leblanc, 2002). These writings generated frameworks and checklists for practice, some combining ideas from employee performance appraisals with insights about the peculiarities of boards (Spencer Stuart, 2017). Theoretical and empirical understanding of board evaluation is, however, comparatively underdeveloped.

The push has met with considerable compliance (cf. Grant Thornton, 2011, 2016), but also with some push-back. Practitioner accounts suggest resistance, acquiescence, but also enthusiasm for a process traditionally associated with staff development and discipline rather than those in the upper echelons.

In the next section we examine how practitioners discuss board effectiveness and how scholars have conceptualize it, and then explore the emerging literature on board evaluation. Integrating the two, the paper develops a revised model of board effectiveness, and develops of a research agenda with implications for practice and policy. We conclude with observations about factors that practitioners, boards and facilitators might consider in designing evaluation exercises.

\section{Board effectiveness}

The work of boards involves complex interactions of individuals in which independence of mind fosters both benefits and threats to effectiveness (Van den Berghe \& Baelden, 2005). In 
theorizing board cognition and effectiveness, Forbes and Milliken (1999) write that boards differ from conventional groups in that they are "large, elite, and episodic decision-making groups that face complex tasks pertaining to strategic-issue processing”. But they are large (typically a dozen or more); the presence of outside, or "non-executive" directors, who serve the company only parttime may mean less than full commitment; and their elite make-up holds the promise and threat of strong individuality. Moreover, boards perform two distinct and at times contradictory roles (Krause, Semadeni, \& Cannella, 2013): service (providing advice), and control (supervising and disciplining).

Moreover, "outside" non-executives become insiders, and the "inside" executives to step outside of their roles as managers. This role ambiguity creates the liminality in which creativity can develop (Concannon \& Nordberg, 2018), but only by suspending the hierarchy. This is not to say that boards are theoretically or empirically without hierarchy. But since Cadbury (1992), policy in the UK and jurisdictions that followed its lead, has sought to counteract it by separating the roles of chairman and CEO and enhancing director independence, and thus - in theory - their effectiveness. $^{2}$

Forbes and Milliken (1999) identify key processes of corporate boards: their effort norms; how they use their knowledge and skills; and the more complex one of "cognitive conflict." The last is vital to challenging senior managers and the chief executive, even though it threatens cohesiveness. And cohesiveness itself is double-edged; boards can be too friendly.

A benefit of the Forbes and Milliken (1999) approach is that it seeks to identify elements that can either be verified externally or where suitable proxies exist. Board demography and the mix of knowledge and skills on the board yield information that is likely to affect the "black box" of board processes. For example, one study demonstrated a lack of confidence among directors about 
their peers' abilities to deal with complex financial matters and risk (Ingley \& van der Walt, 2008). Effort norms can be estimated by the increasingly common corporate reporting of attendance at board and committee meetings. But such metrics leave out two elements that have been prominent in policy and in the literature: board structures and the social characteristics of directors.

Zahra and Pearce (1989) note the importance of structures in shaping the work of boards, while Nordberg and McNulty (2013) show the centrality of structure in shaping policy. Structural mechanisms include elements such as the balance of executive and non-executives directors, often called board independence (Chen, 2011; Johanson \& Østergren, 2010); CEO duality (Krause, Semadeni, \& Cannella, 2014); and board committees (Yeh, Chung, \& Liu, 2011). Board structure is not only a tool for monitoring; it can also signal effectiveness through highlighting access to external resources (Certo, 2003).

Other scholars warn of the limitations of relying on structures in understanding effectiveness of boards (e.g. Roberts, 2002). Kim and Cannella (2008), for example, suggest that such social capital is an important factor in director selection as it contributes to later board effectiveness.

While aspects of such contributions can be assessed with publicly disclosed information, others require personal contact. Leblanc and Gillies (2005) find that director effectiveness, defined as the ability of directors to influence outcomes, can be traced to three factors: their persuasiveness, the predictability of a director's dissent and consensus, and whether a director's orientation was individualistic or collectivist. Of these, persuasiveness is "by far the most important" (Leblanc \& Gillies, 2005). Persuasiveness can help to overcome skepticism and build trust, thus reinforcing cohesiveness when challenged by cognitive conflict. Nicholson and Kiel (2004b) see "board intellectual capital", a composite of board- and director-level factors, as 
contributing to effective decision-making. Like Leblanc and Gillies (2005), they focus attention on social interactions as central to board dynamics.

With similar intent, Charas (2015) posits that directors' "cultural intelligence" plays an important role in effectiveness. She draws upon Earley and Mosakowski (2004b), who reflect "how able people are to empathize, work with, direct, and interact with other people", which facilitates behavioral change in complex situations (Triandis, 2006). This characteristic of directors would seem to help them cope with the tensions between cognitive conflict and board cohesiveness by preventing cohesiveness from tipping into groupthink and cognitive conflict from engendering affective conflict. An overview of their themes appears in Table 1.

Insert Table 1 about here

This points us towards a relationship, under-articulated in the Forbes and Milliken (1999) model, in which director characteristics influence effort norms, cognitive conflict, and board cohesiveness, and perhaps the degree to which they use their knowledge and skills. Forbes and Milliken (1999) see the relationship between conflict and cohesion and central to board effectiveness. But cognitive conflict works against the cohesiveness needed to keep their often large, elite membership headed towards a decision.

Recent empirical evidence suggests that boards develop coping routines to overcome the tension between their service and control functions (Nicholson, Pugliese, \& Bezemer, 2017), performance of which is influenced by cognitive conflict and cohesiveness. In a rare study analyzing video evidence of board deliberations, Nicholson et al. (2017) find directors engage in "systematic and routine behaviours that initially appear paradoxical".

Cultural intelligence, persuasiveness, and the development of coping routines are characteristics and behavior that are difficult to assess through public disclosure. They form 
pressure points that would seem to affect the processes of effort levels, boardroom challenge and the delivery of skills and knowledge central to board effectiveness. Doing so is difficult, however, without the ability of observe the board in action, of which the study by Nicholson et al. (2017) is a very rare example. From practical and policy perspectives, difficulties in gaining access place the onus on board evaluation.

How these relationships work in practice is, therefore, an area of current and important investigation. Moreover, other scholars point to the quality of information provided to directors and similar mundane aspects of the work of boards as contributing to board effectiveness as inputs to board processes (Roy, 2011; Zhang, 2010), in which developments of technology can contribute to shaping the decision-making of boards (Massie, 2015). With those factors lying behind effectiveness, what can we learn about how to evaluate them?

\section{Evaluating boards}

The nascent literature on board evaluation is dominated by practitioner experiences and process prescription to inform policy for board evaluation (Cutting \& Kouzmin, 2002; Nicholson \& Kiel, 2004a). Heracleous and Lan (2002) offer a 20 -question tool to evaluate directors, focusing on their knowledge and skills, that is, inputs to board work, but not their behaviour or performance. Aly and Mansour (2017) reconstruct the balanced scorecard in Kaplan and Norton (1992) to take into account customer-oriented metrics to the work of boards.

Accounts by Kiel, Nicholson, and Barclay (2005) and Kiel and Nicholson (2005) present a seven-step process: the objectives, who will be evaluated, what will be evaluated, who will be asked, what techniques will be used, who will conduct the evaluation, and what will be done with the results. 
Minichilli, Gabrielsson, and Huse (2007) condense these seven into four: who evaluates, content, audience, and conduct. They then use two of them - the evaluator (internal or external) and the "addressee" (internal or external) - to devise an analytic framework in which audiences imply a broad category of purpose: External users, including shareholders, regulators, and other stakeholders, expect compliance. Internal users - directors, committees, and the board as a whole - and some other users (academics and researchers) who sit on the cusp - share the goal of board improvement. If evaluation does lead to greater effectiveness, then the organization can use it to demonstrate its compliance to external audiences. We start our analysis looking at the purpose and conduct of evaluation, who evaluates, and finally content.

\subsection{Purpose and conduct of evaluation}

Writing about evaluation work in general, Fetterman (2001) argues that evaluators not only judge performance; they collaborate in its improvement. Long (2006) also argues for a focus on internal purposes: Evaluation encourages teamwork and improves leadership, she claims. Being evaluated contributes to directors' identification with the board and organization. This suggests candid board evaluation can encourage boardroom challenge even as it builds cohesiveness.

Empirical studies are few and far between, but they support the contention that evaluation can change board dynamics. A survey of company secretaries of 29 UK listed companies described whether and if what form evaluations took place and with want consequences (Dulewicz \& Herbert, 2008). It found that evaluations led to director resignations in a third of the cases (cited in Nicholson, Kiel, \& Tunny, 2012). However, the limited sample size raises questions about how to interpret the responses.

On conduct, studies show a split between accountability-driven concern for verifiable approaches and examination of relational considerations. Some writers argue that boards need to 
measure individual director and group competencies (Cascio, 2004), supplemented by upward feedback and peer review (Garratt, 1999). Others seek more nuanced insights from evaluation. Huse (2005) suggests that to understand board behavior, processes need to be observed and assessed. This suggests a qualitative, ethnographic inquiry.

In a study of board dynamics of family firms, Vandebeek, Voordeckers, Lambrechts, and Huybrechts (2016) see evaluations helping to erode hierarchy and heighten challenge and cohesiveness. That creates liminality in the boardroom (Concannon \& Nordberg, 2018) despite the natural hierarchy of the owner-manager-director.

Beneficial effects are not the only possible outcome, however. A questionnaire-and-interview study of Norwegian boards found that directors saw evaluation serving hygienic purposes (i.e. conforming to external demands for board evaluation) rather than enhancing board performance (Rasmussen, 2015). If such outcomes are conspiratorial, they may increase cohesiveness but at the expense of cognitive conflict. Done manipulatively, they could damage cohesiveness and increase conflict. This study suggests directors may see evaluations as serving mainly cosmetic goals, irrespective of the processes used or who evaluates.

\subsection{Who evaluates}

As board evaluation was beginning to emerge as a corporate governance imperative, Conger, Finegold, and Lawler (1998) observed: "The most obvious impediment to periodic board evaluations is that no one can perform them but the board itself." Boards sit at the top of corporate hierarchies, after which there is no point of appeal. This assertion has been overtaken by events now that policy has embraced the use of external facilitators, so boards have little choice. Both Kiel and Nicholson (2005) and Minichilli et al. (2007) identify a range of options, and we focus 
here on the three categories that embrace the others: self-evaluation, externally facilitated evaluation, and evaluation led by the chair.

Self-assessment. Minichilli et al. (2007) view self-evaluation as a valuable tool for improvement as it provides time and space for self-reflection on board processes and internal culture, such as decision-making, trust, emotions and board interactions. They argue that directors can be open about feelings during the self-evaluation as the processes will be kept confidential from outsiders. Internal evaluation also alleviates concerns over commercial confidentiality (Rasmussen, 2015). Kiel and Nicholson (2005) argue that with selection of a trusted person to lead it, internal evaluation provides "open and honest feedback". However, others see internal evaluation inhibiting openness about problematic board dynamics (Ungureanu, 2013). There are also reasons to doubt whether boards can achieve the impartiality needed for self-evaluation. Writing about personal psychology, Billow (2011) says self-awareness remains tentative, uncertain and evolving. Such concerns lie behind the policy push for external evaluation.

External facilitation. Practitioner articles, theorists, and policy directives assert that effective evaluation of behavior requires an external view (e.g. Pitcher, 2014). With outside experts without vested interests but who understand group dynamics, assumptions of monolithic behavior in group decision-making are removed. For boards, this can help to recognize the dysfunctional group dynamics reported by Conger et al. (1998). Inviting the evaluator to attend meetings on a regular basis can prevent groupthink (Bernthal \& Insko, 1993). If subjectivity and self-interest is present in self-evaluations (Conger et al., 1998) then external facilitation can help. According to Machold and Farquhar (2013), an "informed outsider" can challenge "deep-routed beliefs" of directors and offer "opportunities for reflection to both the researchers and the board members." 
In contrast to the inherent hierarchy evident in employee appraisals, external evaluators need not be viewed as standing in judgment over the board. Writing in the context of general, rather than board-specific evaluation, Ensminger, Kallemeyn, Rempert, Wade, and Polanin (2015) suggest evaluators resemble coaches, guiding toward optimum performance (a view endorsed for boards by Independent Audit, 2016).

There is a danger that boards or individual directors may change behavior under observation, putting the validity of the evaluation into doubt. Politicking may also take place outside the boardroom, which external evaluators may not see. Bailey and Peck (2013) suggest that coalitionbuilding behind the scenes influences boardroom dynamics, which can also affect board decisionmaking (van Ees, Gabrielsson, \& Huse, 2009). An evaluator needs to be alert to politics within the group and the history of the dynamics informing the relevant relationships.

Evaluation by chair - a hybrid model? Practitioner accounts suggest that a common method of board evaluation is for the chairman to conduct evaluations. We have found no study that focuses on this approach specifically, but the practice arguably combines the confidentiality of internal evaluation with some degree of the distance provided by external facilitators. It could as easily lack the objectivity, be subject to the politics, and damage the already tense relationship between boardroom challenge and the sense of common purpose.

This discussion suggests the choice of the evaluator will influence both the types of data that will be collected and the approach to analysis. Internal or external evaluations may draw upon both verifiable metrics and observational approaches. Externally led evaluations may lack subject expertise and a rounded view of the business context that an insider would have, but they bring impartiality. These trade-offs seem to lie beneath the policy preference for external facilitation, 
but not all the time. Whoever conducts the evaluation will nonetheless need to consider the question of what will be evaluated.

\subsection{Content of evaluation}

If the objective is to improve performance, then it seems logical to consider what the literature tells us about board effectiveness. This might includeactivities and resources of the board, emphasizing its strategic role (Conger et al., 1998) and inputs and processes, including information management (Epstein \& Roy, 2005). As discussed above, some factors can be assessed without direct access to the boardroom, but others - behavior and social skills - seem to require observation or personal assessment.

Director characteristics. Demographic characteristics are known, and career details provide many insights about knowledge and skills of individual directors. Assessing the social capital of directors may be possible to an extent from the outside, as studies of board interlocks and social networks have shown. But insofar as social capital involves the interpersonal relations on the board, which lead to cognitive conflict and board cohesiveness, the proxies used in such outside methods would seem to be of little use. Moreover, such data sources will say little about the person's persuasiveness (Leblanc, 2005), thought processes (Earley \& Mosakowski, 2004b), or sensitivity to cultural differences (Charas, 2015). Such personal characteristics may be difficult to judge in peer-based evaluations or those with the chairman as evaluator. The literature further suggests that a crucial link between board evaluation and how director social characteristics relate to cognitive conflict and use of knowledge and skills. Doing so seems to point not just to external evaluation but also more ethnographic approaches of board observation, such as used in the research by Nicholson et al. (2017). 
Board characteristics. Forbes and Milliken (1999) identify demography as a board characteristic, that is, the mix of ages, genders, professional backgrounds, and other factors that the board collectively possesses. Diversity is a remedy for excessive cohesiveness, though the results of empirical studies are less clear about the impact on task and firm performance (Homberg \& Bui, 2013; Van der Walt, Ingley, Shergill, \& Townsend, 2006). Many of these characteristics can be determined from the outside. Similarly, director backgrounds provide insights about knowledge and skills. Board structures are increasingly publicly available. Given another current policy imperative to expand board diversity, attention might be directed in the evaluation process to understanding how such demographic considerations influence the conduct of board processes, including the process of evaluation.

Board processes. Because they are difficult to observe, processes are arguably where prior, structure policy prescriptions have failed to forestall malfeasance. Effort norms can be viewed in disclosures of attendance records at board and committee meetings, though only incompletely. How directors use the mix of knowledge and skills cannot be seen from outside. Cognitive conflict is often consciously hidden, becoming apparent only during dysfunction and then only when cohesiveness collapses.

More prosaically, boards hide information for understandable reasons of confidentiality (Zhang, 2010). But all these processes embody political forces, where the effects of director persuasiveness, cultural and emotional intelligence, and to some extent social capital seem likely to come into play. Moreover, processes that might counteract the intent of board structures. For example, the effect of open invitations to executive directors to attend meetings of "independent" audit committees would be difficult to assess without observation. 
Task performance. The outcomes of the board can sometimes be verified through its decisions. Forbes and Milliken (1999) were careful not to posit a direct link between task performance and firm performance; too many factors come between one and the other. In the case of listed companies, many of the most important decisions must be publicly disclosed, providing verification on important matters and occasionally evidence of faltering cohesiveness. But in the Forbes and Milliken (1999) model, the difficult, inverted U relationship between cohesiveness is the one most in need of evaluation, and its tipping point is one that seems difficult to assess even by someone impartial and on the inside of all decisions. Seeing how director social characteristics play into board cohesiveness and into the difficult relationship between cohesiveness and cognitive conflict argues for external evaluation. With a skilled chair evaluating, whose persuasiveness (Leblanc \& Gillies, 2005) signals sensitivity to the social setting, the evaluator is still someone involved in the decision process. Evaluating those tense situations would be difficult.

\section{A framework for board evaluation}

The preceding discussion leads us to identify certain pressure points in board evaluation (Figure 1). By that we mean the factors and relationships between them where in-person evaluation, and more specifically evaluation through external facilitation, are likely to be most beneficial. Our model builds on Forbes and Milliken (1999) with its crucial inverted U between cohesiveness and performance.

Place Figure 1 about here

First, we make explicit the need in evaluation processes for attention to the social characteristics of directors. These are implicit in Forbes and Milliken (1999), but given their importance in the board effectiveness literature, board evaluation exercise would do well to 
understand what they are and how they are put to use. Second, we add structures to the list of board characteristics, giving examples of some that the literature sees as contributing to effectiveness. Third, we add board information to the processes phase in Forbes and Milliken (1999), an area that is under-studying in the literature, but which practitioners say is important to effectiveness. $^{3}$

Some aspects of board evaluation can be assessed at a distance, we suggest, even by complete outsiders, including regulators, corporate governance ratings agencies, and investment analysts. If reporting of the factors, signified in the model by boxes, became standardized, those types of data would provide a high-level analysis needed for portfolio management and policymaking, but perhaps not for decisions by individual boards.

The relationships, signified by arrows, are perhaps more difficult to assess under the circumstances of confidentiality associated with boards. Some of those specified by Forbes and Milliken (1999), in particular process conflicts, feed into task performance are particularly sensitive, but may become apparent during board evaluation (signified by bolded arrows). Relationships we posit for the additional factors may also be accessible to evaluators (signified by the broken arrows).

We believe the framework can serve as a guide for evaluators, whether internal or external, in trying to determine which data to collect and how to collect it. It also provides a basis for developing theoretical insights about the benefits and limitations of board evaluation, as well as a guide to policy to help appreciate where disclosure can add value or face justified resistance. It thus informs an agenda for further research.

The policy direction that motivates this study also seeks internal improvement, though with the intent of restoring external trust and greater accountability. So, how can we achieve both 
objectives, and what role does the method of evaluation play? It also raises questions about the timing of evaluations.

\subsection{Research for board improvement}

As we have discussed, the limited literature on board evaluation suggests that internal, selfevaluation takes different forms, including director self- and peer-assessment or evaluation conducted by the chairman. External evaluation holds the promise of greater objectivity but with risks of mistrust and lack of contextual understanding.

Internal evaluation. The limited literature to date, much of it written by practitioners or practitioner-scholars, suggests that board self-assessment can help diagnose problems. But we see only limited evidence so far concerning how the process of evaluation affects the processes of effectiveness. Qualitative research can help us identify the benefits and limitations of this approach, especially concerning whether evaluation helps to ameliorate the tensions between cognitive conflict and board cohesiveness or lead directors to use the knowledge and skills they possess.

The practice of board evaluation conducted by the chairman also requires specific research. Anecdotal evidence suggests it is one of the most common methods among companies that do not have CEO duality. But the chairman may not be neutral; insofar as the chair steers the work of nominations, the occupant of that post may contribute to dysfunctional as well as functional board dynamics. If so, these factors too suggest we need to understand better the comparative benefits and drawbacks of chair-led evaluations and those undertaken through external facilitation.

External evaluation. The framework developed in this paper points to a need to detect and interpret deficits in cultural and emotional intelligence, social capital, and persuasiveness that the literature associates with board effectiveness. Research could also help to establish whether 
evaluator-as-coach (Ensminger et al., 2015) might enhance individual director performance or alter group dynamics. Case studies can investigate the varieties of processes and evaluation techniques in use and document contingencies associated with special circumstances (i.e. at times of low, medium or high pressure) when evaluations occur.

Moreover, external facilitators are better placed than researchers to identify problem areas that receive scant if any attention in the literature reviewed here. The problem of "divisive cliques" (Tricker, 2015) and other dysfunctional practices in boards is something an external facilitator is in privileged position to solve. Research into external facilitation might collect such insights, which can deepen our understanding of board as well as to improve board practice and the practice of facilitation.

\subsection{Research for compliance and accountability}

The policy push for board evaluations was motivated by repeated waves of corporate malfeasance among large, listed corporations. Policy sees such evaluations as ways to enhance the accountability of boards to their investors. Such actions help not only to improve task performance but also to build confidence of those outside that such action is being undertaken seriously. However, it is difficult to determine whether the effort is merely for compliance.

Internal evaluation. Practitioner and academic accounts suggest that, performed in a conscientious and constructive way, boards' self-evaluation can generate information with implications for investors. While such information is rarely disclosed, cognitive conflict occasionally becomes public in leaks about boardroom dissent or open hostility between directors. These observations point to a need for research with investors over the adequacy of current reporting measures about the observable characteristics of effectiveness. Research with investment managers might help establish the usefulness of disclosures concerning the 
justifications for or remedial actions taken when effort appears to fall below the norm. Similar questions could be raised about other board characteristics or processes that become the subject of internal board discussion and evaluation.

External evaluation. The use of an external facilitator for board evaluations is increasingly a reporting requirement and a signal of the adoption of best practice. Such reports are increasingly used by corporate governance by governance ratings agencies to assist investment managers with voting. Research with investment managers could help to establish the perceived usefulness of externally led exercises. In this regard it would be useful for research to distinguish between the types of uses, whether for investment decisions (i.e. buy-sell-hold; lend-or-not), voting decisions, or understanding investor engagement and stewardship (McNulty \& Nordberg, 2016).

This analysis also suggests that using external evaluation for compliance with external accountability can be a waste of resources and point to a missed opportunity for improvement. If compliance with policy targets slips into symbolic management, the appearance of best practice may even send false signals (Westphal \& Zajac, 1998). Here research with boards as well as investment managers would help to distinguish the frequency and perception of such actions and warn about the limitations of policy prescriptions for board evaluation.

\subsection{When to evaluate}

The policy environment in many countries is pressing for regular board evaluations, generally annually, and for externally facilitated ones less frequently. By their regularity, such periodic recommendations seem to satisfy the need for compliance and accountability. But as the discussion above has indicated, the value of compliance-oriented evaluation may lead to symbolic management and discourage having external evaluators present at the time when important decisions are on the board's agenda. 
One of the issues is whether boards might be better advised to conduct evaluations not so much periodically, but rather when serious issues feature prominently. Boards might feel it a distraction to have an extra person in the room during sensitive decision-making, however well trusted that person might be. But learning about the sources of conflict, whether cognitive or affective in nature, and what issues excessive cohesiveness brings would be better observed and managed in a setting of important decisions. For example, Mellahi (2005) found that behavioral dynamics influences the poor decision-making ahead of the 2003 failure of Australian firm HIH. Research might help us learn whether evaluations undertaken in the moderate heat of important decisions can improve later outcomes when existential issues arise. It could also help address questions about the efficacy of annual evaluation advocated in policy.

\subsection{Moving things forward}

This paper suggests further research would help corporations deal with needs for board improvement and external accountability. The policy agenda would also benefit from a better understanding the limitations as well as the possibilities of specifying board processes and setting reporting requirements, as well as how to conduct public reporting (McIntyre \& Murphy, 2008). Sponsorship by professional bodies like the Society for Corporate Governance in the US or the Institute of Company Secretaries and Administrators in the UK could help overcome barriers to access and benefit both corporations themselves and policymakers and open a wider path to professionalization of evaluation work. The research agenda outlined here would benefit from a combination of qualitative, ethnographic and interview-based research, survey-based study of practices and effects-based quantitative work on the relationship between board evaluation and various measures of board effectiveness and investor actions. 
A potential extension of such research concerns the use of evaluations for improving the performance of boards on private companies and non-corporate entities like charities, social enterprises and government agencies, and even boards of subsidiaries of larger corporations. Many adopt corporate governance practices designed for listed companies, and anecdotal evidence as well as corners of the growing literature on board evaluations suggests these too would benefit from attention to ideas sketched above.

None of the research we reviewed considers in any detail a practical matter: the cost of board evaluation, in evaluator fees and director time. In relation to the revenues of a large listed company they are probably insignificant, but they become more so the smaller the enterprise. As a proportion of the operating costs of the board itself they can be large, through external facilitation and in director time. Any research undertaken could help us also to understand the benefits and costs.

\section{Conclusions}

Board evaluation is firmly on the agenda of corporations, policymakers and academics. This paper makes some tentative steps towards theorizing board evaluation and its potential for impact on the elusive problems associated with understanding how director characteristics and board processes and structures contribute to effective deliberations. In highlighting the internal- and external-facing purposes of evaluations and the differences made through the two main contrasting methods of evaluating, it points to a research agenda of academic interest but also of importance to corporations and policy in corporate governance.

By adapting and integrating different conceptualizations of board effectiveness we provide an analytic framework that can be used to explain some of the unanswered questions in the developing literature of board evaluation. It also has practical uses for companies seeking to 
undertake board evaluations and for policymakers in understanding the limitations and even unintended consequences of mandating use of the practice. For those involved in the work of board evaluation - whether internally conducted or externally facilitated - with further development this tool can provide a template for the conduct of board evaluations that can add value as well as highlight potential areas of risk.

\footnotetext{
${ }^{1}$ While the original UK recommendation for external facilitation applied only to larger listed companies (those in the FTSE350 index), the latest version of the code (FRC, 2018) extended it to all companies but applied the every-third-year frequencies to the FTSE350. It also urged fuller disclosure of how evaluations were conducted, including the "nature and extent of an external evaluator's contact" with directors, the outcomes, and action taken.

2 Two-tier boards are a special case, where all directors are non-executive and so have greater independence but also constrained information access (Bezemer, Peij, de Kruijs, \& Maassen, 2014).

${ }^{3} \mathrm{We}$ are grateful for this observation to a participant at the British Academy of Management conference in 2017, where we presented this paper.
}

\section{References}

Aly, A. H. and Mansour, M. E. (2017), "Evaluating the sustainable performance of corporate boards: the balanced scorecard approach", Managerial Auditing Journal, Vol. 32 No. 2, pp. 167-195.

Archer, D. and Cameron, A. (2017), "Board evaluations", Governance Newsletter No. 275, pp. 7.

Bailey, B. C. and Peck, S. I. (2013), "Boardroom Strategic Decision-Making Style: Understanding the Antecedents", Corporate Governance: An International Review, Vol. 21 No. 2, pp. 131-146.

Bernthal, P. R. and Insko, C. A. (1993), "Cohesiveness without Groupthink", Group \& Organization Management, Vol. 18 No. 1, pp. 66-87.

Bezemer, P.-J., Peij, S., de Kruijs, L. and Maassen, G. (2014), "How two-tier boards can be more effective", Corporate Governance: The International Journal of Business in Society, Vol. 14 No. 1, pp. 15-31.

Billow, R. M. (2011), "It's All About 'Me': On the Group Leader's Psychology", Group Analysis, Vol. 44 No. 3, pp. 296-314. 
Cadbury, A. (1992), "The Financial Aspects of Corporate Governance", available at: http://www.ecgi.org/codes/documents/cadbury.pdf (accessed September 1 2015).

Cadbury, A. (1999), "What are the trends in corporate governance? How will they affect your company?", Long Range Planning, Vol. 32 No. 1, pp. 12-19.

Cascio, W. F. (2004), "Board governance: A social systems perspective", Academy of Management Executive, Vol. 18 No. 1, pp. 97-100.

Certo, S. T. (2003), "Influencing Initial Public Offering Investors with Prestige: Signaling with Board Structures", The Academy of Management Review, Vol. 28 No. 3, pp. 432-446.

Charas, S. (2015), "Improving corporate performance by enhancing team dynamics at the board level", International Journal of Disclosure and Governance, Vol. 12 No. 2, pp. 107-131.

Chen, H.-L. (2011), "Does Board Independence Influence the Top Management Team? Evidence from Strategic Decisions toward Internationalization", Corporate Governance: An International Review, Vol. 19 No. 4, pp. 334-350.

Concannon, M. and Nordberg, D. (2018), "Boards strategizing in liminal spaces: Process and practice, formal and informal", European Management Journal, Vol. 36 No. 1, pp. 71-82.

Conger, J. A., Finegold, D. and Lawler, E. E., III. (1998), "Appraising boardroom performance", Harvard Business Review, Vol. 76 No. 1, pp. 136-148.

Cornforth, C. (2001), "What Makes Boards Effective? An examination of the relationships between board inputs, structures, processes and effectiveness in non-profit organisations", Corporate Governance: An international review, Vol. 9 No. 3, pp. 217-227.

Cutting, B. and Kouzmin, A. (2002), "Evaluating corporate board cultures and decision making", Corporate Governance: The international journal of business in society, Vol. 2 No. 2, pp. 27-45.

D'Amato, A. and Gallo, A. (2016), "Does Bank Institutional Setting Affect Board Effectiveness? Evidence from Cooperative and Joint-Stock Banks", Corporate Governance: An International Review, Vol. 25 No. 2, pp. 78-99.

Dahya, J. and Travlos, N. G. (2000), "Does the one man show pay? Theory and evidence on the dual CEO revisited", European Financial Management, Vol. 6 No. 1, pp. 85-98.

Del Guercio, D., Dann, L. Y. and Partch, M. M. (2003), "Governance and boards of directors in closed-end investment companies", Journal of Financial Economics, Vol. 69 No. 1, pp. 111152. 
Dulewicz, V. and Herbert, P. (2008), "Current practice of FTSE 350 Boards concerning the appointment, evaluation and development of directors, boards and committees post the Combined Code", International Journal of Business Governance and Ethics, Vol. 4 No. 1, pp. 99-115.

Earley, P. C. and Mosakowski, E. (2004a), "Cultural Intelligence", Harvard Business Review, Vol. 82 No. 10, pp. 139-146.

Earley, P. C. and Mosakowski, E. (2004b), "Toward Culture Intelligence: Turning Cultural Differences into a Workplace Advantage", Academy of Management Executive, Vol. 18 No. 3, pp. 151-157.

Ensminger, D. C., Kallemeyn, L. M., Rempert, T., Wade, J. and Polanin, M. (2015), "Case study of an evaluation coaching model: Exploring the role of the evaluator", Evaluation and Program Planning, Vol. 49, pp. 124-136.

Epstein, M. J. and Roy, M.-J. (2005), "Evaluating and monitoring CEO performance: evidence from US compensation committee reports", Corporate Governance: The international journal of business in society, Vol. 5 No. 4, pp. 75-87.

Fetterman, D. M. (2001), "The transformation of evaluation into a collaboration: a vision of evaluation in the 21st century", American Journal of Evaluation, Vol. 22 No. 3, pp. 381-385.

Forbes, D. P. and Milliken, F. J. (1999), "Cognition and corporate governance: Understanding boards of directors as strategic decision-making groups", Academy of Management Review, Vol. 24 No. 3, pp. 489-505.

FRC. (2010), "The UK Corporate Governance Code", available at: http://www.frc.org.uk/documents/pagemanager/Corporate_Governance/UK\%20Corp\%20Go v\%20Code\%20June\%202010.pdf (accessed May 29 2010).

FRC. (2018), "The UK Corporate Governance Code", available at: https://www.frc.org.uk/getattachment/88bd8c45-50ea-4841-95b0-d2f4f48069a2/2018-UKCorporate-Governance-Code-FINAL.pdf (accessed July 17 2018).

Garratt, B. (1999), "Developing Effective Directors and Building Dynamic Boards", Long Range Planning, Vol. 32 No. 1, pp. 28-35.

Grant Thornton. (2011), "Corporate Governance Review 2011 - A changing climate, fresh challenges ahead", available at: http://www.grantthornton.co.uk/pdf/Corporate_Governance_Review_2011.pdf(accessed November 28 2011). 
Grant Thornton. (2016), "Corporate Governance Review 2016", available at:

http://www.grantthornton.co.uk/globalassets/1.-member-firms/unitedkingdom/pdf/publication/2016/2016-corporate-governance-review.pdf (accessed February 14 2017).

Heracleous, L. and Lan, L. L. (2002), "Who wants to be a competent director?: An evaluation tool of directors' knowledge of governance principles and legal duties", Corporate Governance: The international journal of business in society, Vol. 2 No. 4, pp. 17-23.

Homberg, F. and Bui, H. T. M. (2013), "Top Management Team Diversity: A Systematic Review", Group \& Organization Management, Vol. 38 No. 4, pp. 455-479.

Huse, M. (2005), "Accountability and Creating Accountability: a Framework for Exploring Behavioural Perspectives of Corporate Governance", British Journal of Management, Vol. 16 No. S1, pp. S65-S79.

Independent Audit. (2016), "Board development not board evaluation", available at: http://independentaudit.com/wp-content/uploads/2016/04/Board-Development-not-BoardEvaluation-Podcast-transcript-May-2016.pdf (accessed February 12 2017).

Ingley, C. and van der Walt, N. (2008), "Risk Management and Board Effectiveness", International Studies of Management \& Organization, Vol. 38 No. 3, pp. 43-70.

Johanson, D. and Østergren, K. (2010), "The Movement Toward Independent Directors on Boards: A Comparative Analysis of Sweden and the UK", Corporate Governance: An International Review, Vol. 18 No. 6, pp. 527-539.

Johnson, S. G., Schnatterly, K. and Hill, A. D. (2013), "Board Composition Beyond Independence: Social Capital, Human Capital, and Demographics", Journal of Management, Vol. 39 No. 1, pp. 232-262.

Jones, V. (2011), "Board evaluations and effectiveness reviews", available at: http://www.icaew.com/en/technical/corporate-governance/uk-corporate-governance/boardevaluations-and-effectiveness-reviews (accessed October 29 2017).

Kakabadse, A., Kakabadse, N. K., Moore, P., Morais, F. and Goyal, R. (2017), "Conflict and Tension in the Boardroom", available at: https://www.icsa.org.uk/knowledge/research/theconflict-and-tension-in-the-boardroom-report/ (accessed July 22 2017).

Kaplan, R. S. and Norton, D. P. (1992), "The Balanced Scorecard--Measures That Drive Performance", Harvard Business Review, Vol. 70 No. 1, pp. 71-79. 
Kiel, G. C. and Nicholson, G. J. (2005), "Evaluating Boards and Directors", Corporate Governance: An International Review, Vol. 13 No. 5, pp. 613-631.

Kiel, G. C., Nicholson, G. J. and Barclay, M. A. (2005), Board, Director and CEO Evaluation, McGraw-Hill, Sydney.

Kim, Y. and Cannella, A. A., Jr. (2008), "Toward a Social Capital Theory of Director Selection", Corporate Governance: An International Review, Vol. 16 No. 4, pp. 282-293.

Krause, R., Semadeni, M. and Cannella, A. A. (2013), "External COO/presidents as expert directors: A new look at the service role of boards", Strategic Management Journal, Vol. 34 No. 13, pp. 1628-1641.

Krause, R., Semadeni, M. and Cannella, A. A. (2014), "CEO Duality: A Review and Research Agenda", Journal of Management, Vol. 40 No. 1, pp. 256-286.

Leblanc, R. (2002), "Assessing Board Performance: 10 Key Factors", Corporate Board, Vol. 23 No. 132, pp. 1-6.

Leblanc, R. (2005), "Assessing Board Leadership", Corporate Governance: An International Review, Vol. 13 No. 5, pp. 654-666.

Leblanc, R. and Gillies, J. (2005), Inside the Boardroom: How boards really work and the coming revolution in corporate governance, John Wiley, Mississauga, Ont.

Long, T. (2006), "This Year's Model: influences on board and director evaluation", Corporate Governance: An international review, Vol. 14 No. 6, pp. 547-557.

Machold, S. and Farquhar, S. (2013), "Board Task Evolution: A Longitudinal Field Study in the UK", Corporate Governance: An International Review, Vol. 21 No. 2, pp. 147.

Massie, R. (2015), "Allocating Effort: Risk and Complexity in Board Directors' Engagement with Information", City University, London.

McIntyre, M. L. and Murphy, S. A. (2008), "Board of director performance reporting", Corporate Governance: The international journal of business in society, Vol. 8 No. 2, pp. 165-178.

McKinsey \& Co. (2011), "Governance since the economic crisis: McKinsey Global Survey results", available at: https://www.mckinseyquarterly.com/PDFDownload.aspx?ar=2814\&srid=17 (accessed July 7 2011). 
McNulty, T., Florackis, C. and Ormrod, P. (2013), "Boards of Directors and Financial Risk during the Credit Crisis", Corporate Governance: An International Review, Vol. 21 No. 1, pp. 58-78.

McNulty, T. and Nordberg, D. (2016), "Ownership, Activism and Engagement: Institutional Investors as Active Owners", Corporate Governance: An International Review, Vol. 24 No. 3, pp. 346-358.

McNulty, T. and Pettigrew, A. (1996), "The Contribution, Power and Influence of Part-time Board Members", Corporate Governance: An International Review, Vol. 4 No. 3, pp. 160179.

Mellahi, K. (2005), "The Dynamics of Boards of Directors in Failing Organizations", Long Range Planning, Vol. 38 No. 3, pp. 261-279.

Minichilli, A., Gabrielsson, J. and Huse, M. (2007), "Board Evaluations: making a fit between the purpose and the system", Corporate Governance: An international review, Vol. 15 No. 4 , pp. 609-622.

Murphy, S. A. and McIntyre, M. L. (2007), "Board of director performance: a group dynamics perspective", Corporate Governance: The International Journal of Business in Society, Vol. 7 No. 2, pp. 209-224.

NACD. (2001), "NACD Blue Ribbon Commission on Board Evaluation: Improving director effectiveness", in National Association of Corporate Directors \& Center for Board Leadership. National Association of Corporate Directors, Washington.

Nicholson, G. J. and Kiel, G. C. (2004a), "Breakthrough board performance: how to harness your board's intellectual capital[1]", Corporate Governance: The international journal of business in society, Vol. 4 No. 1, pp. 5-23.

Nicholson, G. J. and Kiel, G. C. (2004b), "A Framework for Diagnosing Board Effectiveness", Corporate Governance: An International Review, Vol. 12 No. 4, pp. 442-460.

Nicholson, G. J., Kiel, G. C. and Tunny, J. A. (2012), "Board evaluations: Contemporary thinking and practice", in Clarke, T. and Branson, D. (Eds.), The Sage Handbook of Corporate Governance. Sage, London, pp. 285-324.

Nicholson, G. J., Pugliese, A. and Bezemer, P.-J. (2017), "Habitual accountability routines in the boardroom: How boards balance control and collaboration", Accounting, Auditing \& Accountability Journal, Vol. 30 No. 2, pp. TBD. 
Nordberg, D. and McNulty, T. (2013), "Creating better boards through codification: Possibilities and limitations in UK corporate governance, 1992-2010", Business History, Vol. 55 No. 3, pp. 348-374.

OECD. (2015), "G20/OECD Principles of Corporate Governance", available at: http://www.oecd-ilibrary.org/docserver/download/2615021e.pdf (accessed March 26 2017).

Pitcher, H. (2014), "Who evaluates the evaluators?", in Governance Newsletter. Governance Publishing \& Information Services Ltd., pp. 8-9.

Rasmussen, J. (2015), "Do Board Evaluations Measure Board Effectiveness?", International Studies of Management \& Organization, Vol. 45 No. 1, pp. 80-98.

Roberts, J. (2002), "Building the Complementary Board. The Work of the Plc Chairman", Long Range Planning, Vol. 35 No. 5, pp. 493-520.

Roy, M.-J. (2011), "Board information: meeting the evolving needs of corporate directors", Management Research Review, Vol. 34 No. 7, pp. 773-789.

Schmidt, S. L. and Brauer, M. (2006), "Strategic Governance: how to assess board effectiveness in guiding strategy execution", Corporate Governance: An International Review, Vol. 14 No. 1, pp. 13-22.

Spencer Stuart. (2017), "Boardroom Best Practice", available at: https://www.spencerstuart.com/ /media/bbp2017/bbp2017_ipe.pdf (accessed November 27 2017).

Triandis, H. C. (2006), "Cultural Intelligence in Organizations", Group \& Organization Management, Vol. 31 No. 1, pp. 20-26.

Tricker, B. (2015), "Throughout the 20th century, the focus had been on management. But where was the board on the management organization chart?", available at: http://www.bobtricker.co.uk/corporate-governance.html (accessed September 1 2015).

Ungureanu, C. (2013), "Board Evaluation: Notes From Europe", Corporate Board, Vol. 34 No. 202, pp. 17-19.

Van den Berghe, L. A. A. and Baelden, T. (2005), "The complex relation between director independence and board effectiveness", Corporate Governance: The International Journal of Business in Society, Vol. 5 No. 5, pp. 58-83. 
Van der Walt, N., Ingley, C. B., Shergill, G. S. and Townsend, A. (2006), "Board configuration: are diverse boards better boards?", Corporate Governance: The international journal of business in society, Vol. 6 No. 2, pp. 129-147.

van Ees, H., Gabrielsson, J. and Huse, M. (2009), "Toward a Behavioral Theory of Boards and Corporate Governance", Corporate Governance: An International Review, Vol. 17 No. 3, pp. 307-319.

Vandebeek, A., Voordeckers, W., Lambrechts, F. and Huybrechts, J. (2016), "Board role performance and faultlines in family firms: The moderating role of formal board evaluation", Journal of Family Business Strategy, Vol. 7 No. 4, pp. 249-259.

Warther, V. A. (1998), "Board effectiveness and board dissent: A model of the board's relationship to management and shareholders", Journal of Corporate Finance, Vol. 4 No. 1, pp. 53-70.

Westphal, J. D. and Zajac, E. J. (1998), "The Symbolic Management of Stockholders: Corporate Governance Reforms and Shareholder Reactions", Administrative Science Quarterly, Vol. 43 No. 1, pp. 127-153.

Yeh, Y.-H., Chung, H. and Liu, C.-L. (2011), "Committee Independence and Financial Institution Performance during the 2007-08 Credit Crunch: Evidence from a Multi-country Study", Corporate Governance: An International Review, Vol. 19 No. 5, pp. 437-458.

Zahra, S. A. and Pearce, J. A., II. (1989), "Boards of Directors and Corporate Financial Performance: A Review and Integrative Model", Journal of Management, Vol. 15 No. 2, pp. 291-334.

Zhang, P. (2010), "Board Information and Strategic Tasks Performance", Corporate Governance: An International Review, Vol. 18 No. 5, pp. 473-487. 


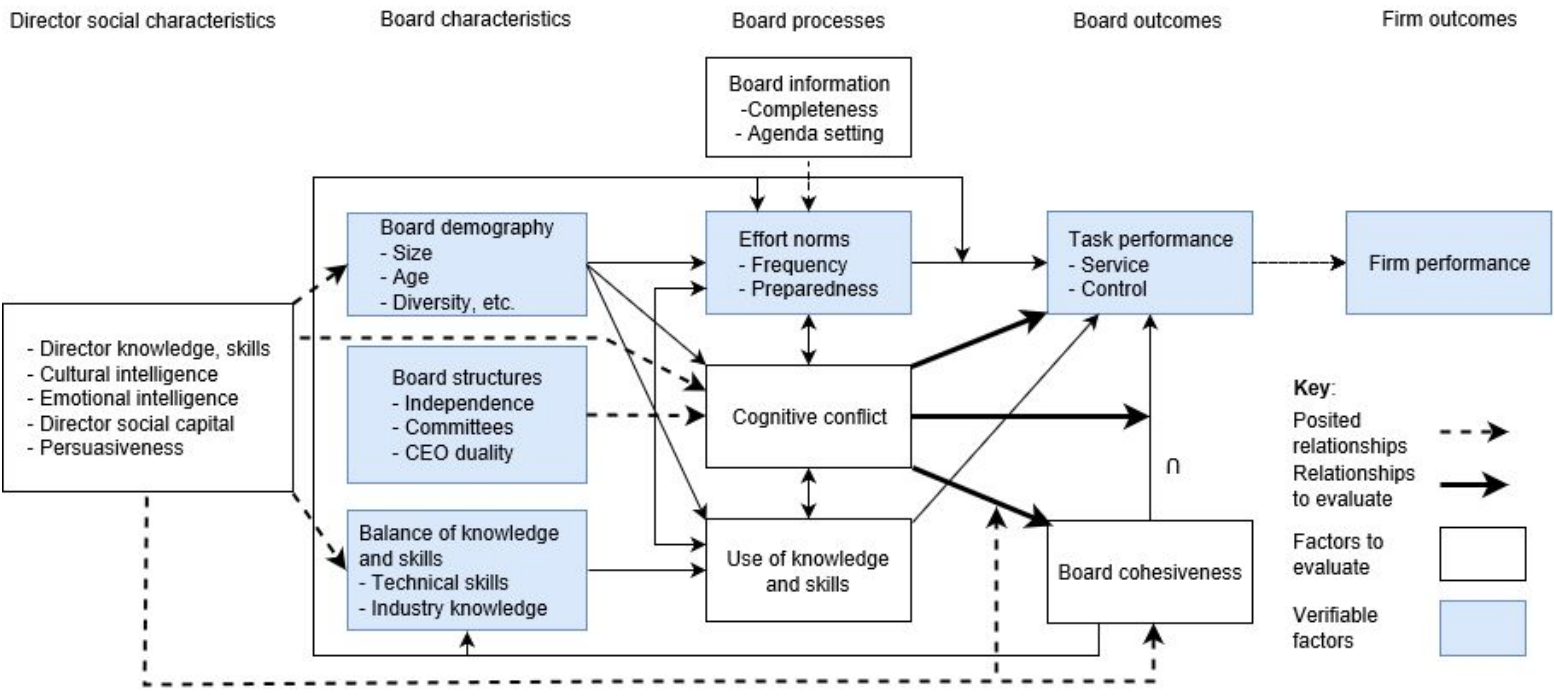

A model of pressure points for evaluating board effectiveness, adapted from Forbes \& Milliken (1999), Nicholson \& Kiel (2004), Leblanc \& Gilles (2005), Charas (2015), Zhana (2010)

\section{Figure 1: Pressure points in board evaluation}


Table 1 - Factors in board effectiveness and evaluation

\begin{tabular}{|c|c|c|}
\hline Theme & Core analyses & Related and supporting literature \\
\hline \multicolumn{3}{|c|}{ Director characteristics, cognition, processes } \\
\hline $\begin{array}{l}\text { Cognition and processes, } \\
\text { highlighting the tensions between } \\
\text { boardroom challenges and group } \\
\text { identification }\end{array}$ & $\begin{array}{l}\text { Forbes and } \\
\text { Milliken } \\
\text { (1999) }\end{array}$ & $\begin{array}{l}\text { Warther (1998); Van den Berghe and Baelden } \\
\text { (2005); Murphy and McIntyre (2007) }\end{array}$ \\
\hline $\begin{array}{l}\text { Directors' social capital and } \\
\text { relationships }\end{array}$ & $\begin{array}{l}\text { Nicholson } \\
\text { and Kiel } \\
\text { (2004b) }\end{array}$ & $\begin{array}{l}\text { Kim and Cannella (2008); Johnson, Schnatterly, and } \\
\text { Hill (2013) }\end{array}$ \\
\hline Sensitivity; cultural intelligence & Charas (2015) & $\begin{array}{l}\text { Earley and Mosakowski (2004a); Triandis (2006); } \\
\text { Roberts (2002) }\end{array}$ \\
\hline Director persuasiveness & $\begin{array}{l}\text { Leblanc and } \\
\text { Gillies (2005) }\end{array}$ & McNulty and Pettigrew (1996) \\
\hline \multicolumn{3}{|l|}{ Structures, processes } \\
\hline $\begin{array}{l}\text { Firm and institutional contingencies } \\
\text { affecting the interplay of structure, } \\
\text { processes and cognition }\end{array}$ & $\begin{array}{l}\text { Zahra and } \\
\text { Pearce (1989) }\end{array}$ & $\begin{array}{l}\text { D'Amato and Gallo (2016); Schmidt and Brauer } \\
\text { (2006); Cornforth (2001); Del Guercio, Dann, and } \\
\text { Partch (2003); Dahya and Travlos (2000); McNulty, } \\
\text { Florackis, and Ormrod (2013) }\end{array}$ \\
\hline Quality of board information & Zhang (2010) & Roy (2011); Massie (2015) \\
\hline
\end{tabular}

